\title{
WATER QUALITY ASSESSMENT USING WATER QUALITY INDEX: A CASE OF THE RAY RIVER, VIETNAM
}

\author{
Phan Thi Thanh Thuy ${ }^{1,2 *}$, Nguyen Van Viet ${ }^{1,2}$, Nguyen Kieu Lan Phuong ${ }^{3}$, Chun-Hung Lee ${ }^{1}$
}

${ }^{I}$ College of Environmental Studies - National Dong Hwa University, Taiwan

${ }^{2}$ Vietnam National University of Forestry - Dong Nai Campus, ${ }^{3}$ Nguyen Tat Thanh University

\begin{tabular}{|c|c|}
\hline ARTICLE INFO & ABSTRACT \\
\hline $\begin{array}{l}\text { KEYWORDS } \\
\text { Classification } \\
\text { Ray River } \\
\text { Surface water } \\
\text { Water quality assessment } \\
\text { Water quality index }\end{array}$ & 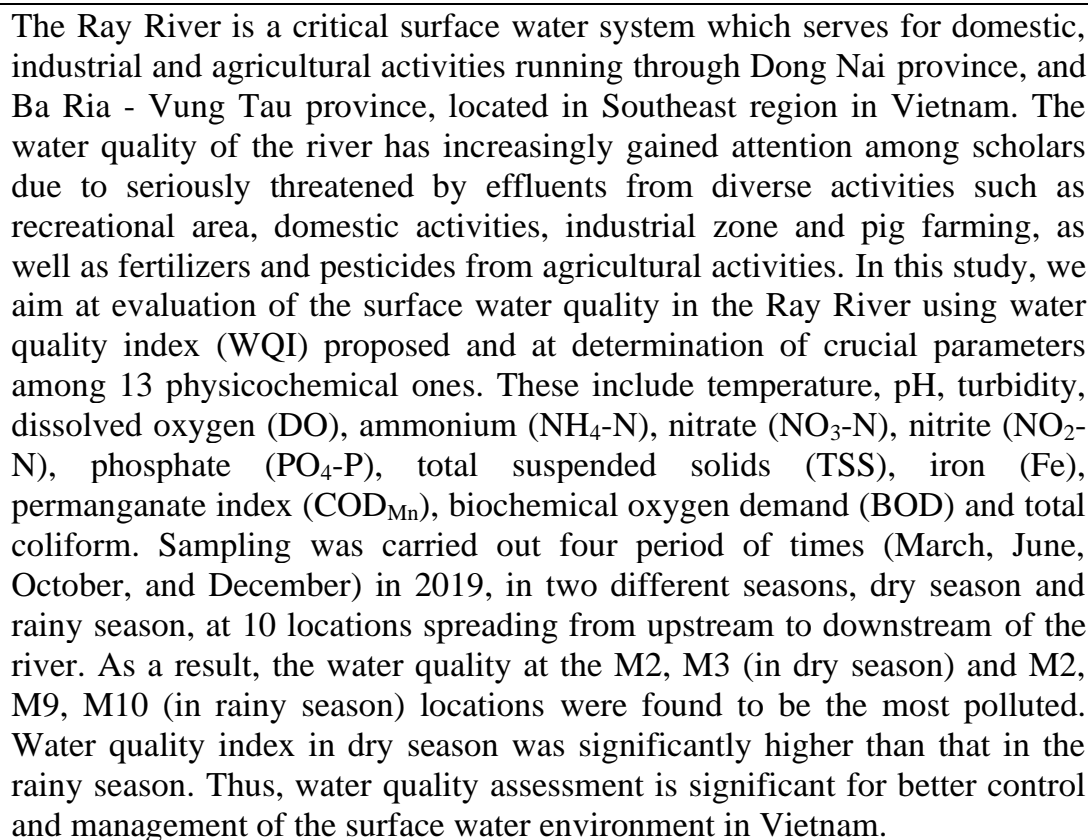 \\
\hline
\end{tabular}

\section{ÚNG DỤNG CHỈ SỐ WQI ĐÁNH GIÁ CHÂTT LƯợNG NƯỚC SÔNG RAY, VIẸTT NAM}

Phan Thi Thanh Thủy ${ }^{1,2^{*}}$, Nguyễn Văn Việt ${ }^{1,2}$, Nguyễn Kiều Lan Phương ${ }^{3}$, Chun-Hung Lee ${ }^{1}$

${ }^{1}$ Viện Nghiên cúu Môi truoòng - Truờng Đại học Quốc gia Đông Hoa, Đài Loan,

${ }^{2}$ Truoòng Đại học Lâm nghiệp - Phân hiệu tại tỉnh Đồng Nai, ${ }^{3}$ Trường Đại học Nguyễn Tất Thành

\begin{tabular}{l} 
THÔNG TIN BÀI BÁO \\
\hline Ngày nhận bài: $18 / 4 / 2021$ \\
Ngày hoàn thiện: $14 / 5 / 2021$ \\
Ngày đăng: $25 / 5 / 2021$ \\
TÙ KHÓA
\end{tabular}

Chất lượng nước

Nước mặt

Phân loại

Sông Ray

WQI (chỉ số chất lượng nước)

\section{TÓM TÁT}

Sông Ray là một trong những hệ thống sông chảy qua tỉnh Đồng Nai và Bà Rịa - Vũng Tàu. Nước sông có tầm quan trọng trong việc phục vụ sinh hoạt, công nghiệp và nông nghiệp. Tuy nhiên, hiện nay chất lượng nước ngày càng ảnh hưởng nghiêm trọng bởi các hoạt động vui chơi giải trí, du lịch, chăn nuôi, phân bón và thuốc trừ sâu. Do đó, nghiên cứu nàyđược thực hiện với mục đích xác định và đánh giá các thông số hóa lý quan trọng. Mẫu được thu định kỳ 4 tháng trong năm 2019 (tháng $3,6,10,12$ ) giữa hai mùa khô và mùa mưa bao gồm 13 thông số hóa lý như nhiệt độ, $\mathrm{pH}$, độ đục, oxy hòa tan (DO), amoni $\left(\mathrm{NH}_{4}-\mathrm{N}\right)$, nitrat $\left(\mathrm{NO}_{3}-\mathrm{N}\right)$, nitrit $\left(\mathrm{NO}_{2}-\mathrm{N}\right)$, photphat $\left(\mathrm{PO}_{4}-\mathrm{P}\right)$, tổng chất rắn lơ lửng $(\mathrm{TSS})$, sắt $(\mathrm{Fe})$, nhu cầu oxy hóa học $(\mathrm{COD})$, nhu cầu oxy sinh học $\left(\mathrm{BOD}_{5}\right)$ và tổng coliform. Phương pháp thu và phân tích mẫu dựa theo phương pháp chuẩn Andrew, 1995. Kết quả sau 4 đợt phân tích mẫu cho thấy chất lượng nước tại các vị trí M2, M3 (mùa khô) và M2, M9, M10 (mùa mưa) bị ô nhiễm nặng nhất. Ngoài ra, chỉ số WQI mùa khô cao hơn mùa mưa. Vì vậy, đánh giá chất lượng nước sông Ray có ý nghĩa quan trọng trong việc kiểm soát và quản lý môi trường nước mặt ở Việt Nam.

DOI: https://doi.org/10.34238/tnu-jst.4385

\footnotetext{
${ }^{*}$ Corresponding author. Email: pttthuy@vnuf2.edu.vn
} 


\section{Introduction}

Rivers provide important water resources for irrigational, industrial, and domestic purposes. Meanwhile, water quality degradation is serious and common worldwide because of numerous stresses, including natural processes, anthropogenic activities and overdevelopment [1]-[3]. Besides, water pollution not only influences water quality but also impacts human health, ecosystem, economic and social development [4]. However, it is impossible to follow the alteration in water quality of a river (or section of a river) through each individual parameter of assessment of water quality and to compare water quality in each section of a river, between one river and another one, or among months or seasons, or between the current water quality and the past one [5]. River basins are likely to be polluted by effluents discharge from domestic, industrial, and agricultural activities. Hence, it is essential to control water pollution and water quality [6], [7]. Some studies have shown that assessment of river water quality using traditional water samples for laboratory analyses is highly accuracy but very costly and time consuming [8], [9]. Water quality assessment has been carried out by various methods such as statistical approach, modelling technique WQI [9]-[11]. Assessing WQI is one of the most useful methods to transmit information of the quality of water to publics and relevant policy makers [12]-[15]. Moreover, WQI have multiple calculations and models of development and to enhance the understanding capacity of water quality issues by policy makers and community [16], [17]. Therefore, developing appropriate WQI for the local area is very important. In recent years, there have been studies of applications of the WQI to evaluate water quality. Şener et al. [18] evaluated the water quality the Aksu river (SW-Turkey) based on water quality index and map. Wu et al. [19] applied a water quality index min (WQI ${ }_{\text {min }}$ ) to assess water quality of rivers in Lake Chaohu Basin. The result showed that $\mathrm{WQI}_{\min }$ consisted of five crucial parameters (i.e., turbidity, DO, $\mathrm{NH}_{4}-\mathrm{N}, \mathrm{NO}_{3}-\mathrm{N}$, and $\mathrm{COD}_{\mathrm{Mn}}$ ) was not significantly different with the WQI based on all the 15 parameters.

Rapid development of industrialization and urbanization, especially in developing countries, e.g. Vietnam, has impacted the availability and quality of surface water due to its overexploitation and improper waste disposal. Vietnam currently has in total 2360 rivers with an average $10 \mathrm{~km}$ long including 109 main rivers [20], [21]. Recently, pollution of rivers in Vietnam has increased steadily such as Sai Gon, Dong Nai, and Ray rivers [22], [23]. The Ray river is of particular importance in the study of surface water pollution because the effluents from $\mathrm{Da} \mathrm{Bac}$ Industrial Zone, pig farm, sewage from Xuyen Moc, Chau Duc and Cam My districts are discharged into this river which ultimately leads to the surface water of the Ray River being seriously threatened by fertilizers, pesticides, farm, and livestock activities. In addition, the Ray River is also the main source of water for domestic, industrial and agricultural activities, so effective water management is essential.

Concerning a number of studies on WQI in Vietnam, Hanh et al. [24] applied a WQI to identify pollutants in Vietnam's surface water. The results showed that surface-water quality in the northern and central parts was poor, containing organic matter, nutrients, and bacteria, whereas water in the southern part was primarily polluted by bacteria and drainage systems, lakes and stretches of rivers close to urban areas had extremely poor water quality. Lan et al. [25] studied of surface water quality by water quality index (WQI) at the Cai Sao canal, An Giang province, Vietnam; the results demonstrated that the WQI model offered a reliable alternative to water quality computation and forecasting. More recently, Pham et al. [26] employed multivariate statistical techniques and WQI to assessment of surface water quality of Dong Nai River Basin, Vietnam. The results showed that multivariate statistical techniques and WQI could be an efficient approach to communicate information on water quality for the sustainable practices of watershed management in the Upper Part of Dong Nai River Basin. However, since the development of the WQI method, to the best of the authors' knowledge, there has been no 
published research demonstrating the application of the WQI index to water quality prediction in the Ray River. On the other hand, an overall water quality evaluation, as well as water quality comparisons of different monitoring sites both within a region and among different regions, had not yet been conducted. Moreover, in this study, we evaluated the water quality condition in the Ray River based on two seasonal sampling activities at ten locations covering the entire basin in 2019. The primary aim of the study was to assess water quality by location and season and to determine the main parameters influence water quality (i.e., the parameters included in WQI). Besides, water quality assessment is significant for the development of nations and to identify database for preparations of future water resources development strategies. Moreover, this research helps to better control and manage surface water environment in Vietnam.

\section{Material and methods}

\subsection{Study area}

The Ray River flows north-south through Dong Nai and Ba Ria - Vung Tau province. It originates from the south and southwest of Chua Chan mountain, has a total catchment area of $1.300 \mathrm{~km}^{2}$ and the length of river is $120 \mathrm{~km}$ (Figure 1).

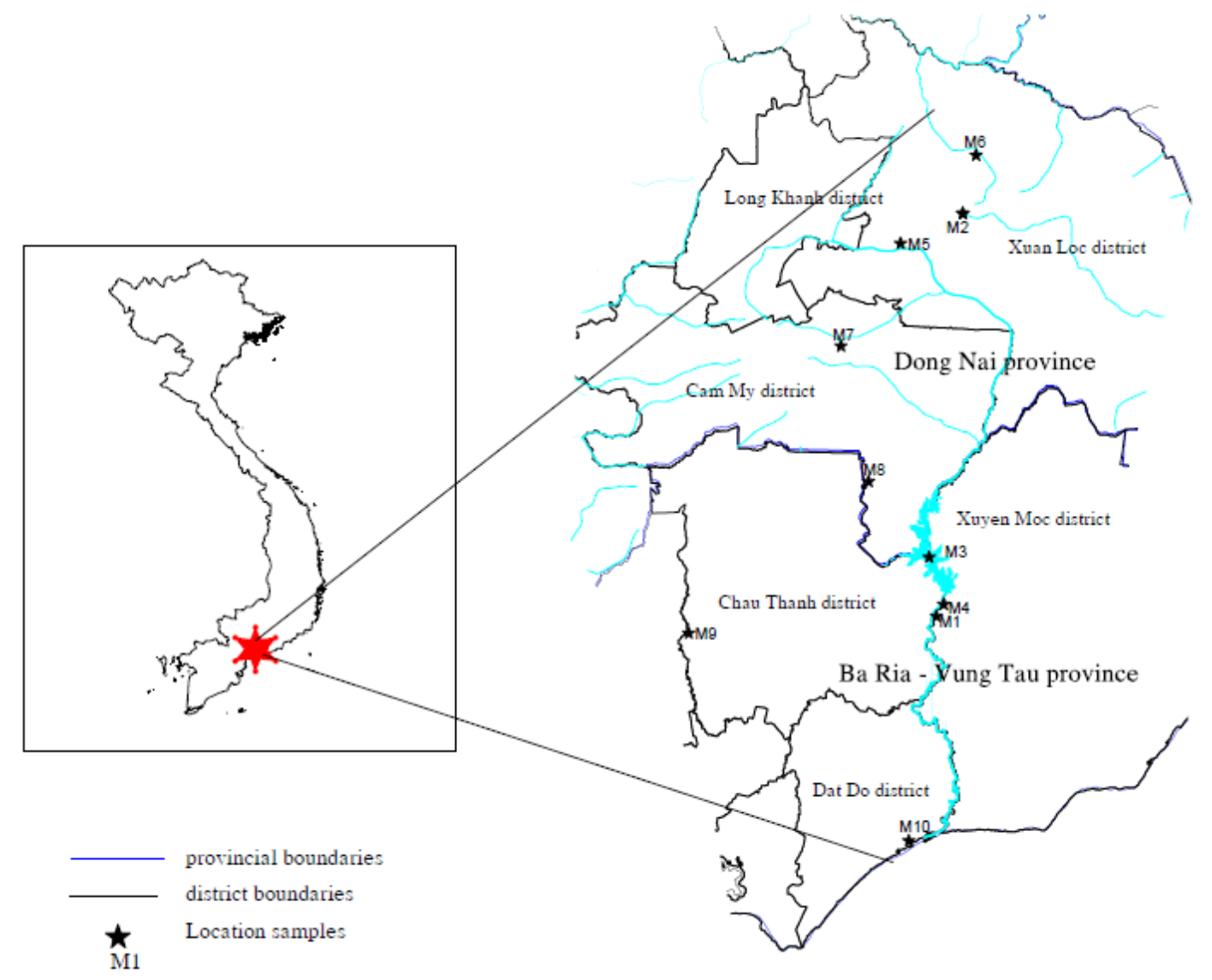

Figure 1. Map of sampling sites

The river network is diverse and subdivided in different tributaries such as Suoi Mon Coum, Suoi Cao, Suoi Sap. There has been an irrigation lake built on the Ray River, which has a total area of more than 2.040 ha [27]. Data was collected throughout the Ray River basin running through the territory of Dong Nai and Ba Ria - Vung Tau provinces, which have the fastest economic growth in Vietnam's Southern Economic Zone with the tropical monsoon climate. The 
Ray River basin provides the main source of water for irrigation, domestic and industrial activities requirements.

\subsection{Sample collection and laboratory analysis}

Sampling was done four periods in March, June, October, and December in 2019, falling into two different seasons, dry season (DS), and rainy season (RS). The sampling locations descriptions are displayed in Table 1 and Figure 1.

Most of the samples were conducted in non-rainy weather conditions. We collected water samples at a depth of $\sim 20 \mathrm{~cm}$ with a plastic bin and acid-cleaned after rinsing with the surface water. The water samples were analyzed using standard procedure [28] such as temperature (T), $\mathrm{pH}, \mathrm{DO}$, turbidity (tur). The parameters nitrate $\left(\mathrm{NO}_{3}-\mathrm{N}\right)$, ammonium $\left(\mathrm{NH}_{4}-\mathrm{N}\right)$, nitrite $\left(\mathrm{NO}_{2}-\mathrm{N}\right)$, phosphate $\left(\mathrm{PO}_{4}-\mathrm{P}\right)$, total suspended solids (TSS), have been filtered by $\mathrm{GF} / \mathrm{F}$ filters before analysis. All samples had been kept by ice in the refrigerator during the study. $\mathrm{pH}$, temperature, DO, and turbidity were analyzed using portable HANA instrument analyzer model HI9828. Irion $(\mathrm{Fe}), \mathrm{NO}_{3}-\mathrm{N}, \mathrm{NH}_{4}-\mathrm{N}, \mathrm{NO}_{2}-\mathrm{N}$, and $\mathrm{PO}_{4}-\mathrm{P}$ were determined by $\mathrm{UV}$ spectrophotometer model SPECTRO 24RS. Permanganate index (COD $\left.\mathrm{Mn}_{\mathrm{Mn}}\right)$ was determined by using titrimetric method and acid digestion with potassium permanganate oxidation.

Biochemical Oxygen Demand (BOD) was measured using oxytop equipment and incubated in a closed system. TSS was determined by using mass method. Total coliform was measured using Membrane-filter technique method, by growing on M-FC medium at temperature $44.5^{\circ} \pm 1^{\circ} \mathrm{C}$ and counted after 48 hours.

Table 1. Sampling locations in Ray River

\begin{tabular}{|c|c|c|}
\hline Location & Code & Description \\
\hline $\begin{array}{l}\text { Hoa Binh } \\
\text { waterfall }\end{array}$ & M1 & $\begin{array}{l}\text { The sampling location is located near recreational area (picnic areas) agricultural area } \\
\text { and pig farm. }\end{array}$ \\
\hline $\begin{array}{l}\text { Upstream of the } \\
\text { Ray River }\end{array}$ & M2 & $\begin{array}{l}\text { The sampling location is located near livestock and farm, which is the upstream } \\
\text { location. Activities observed are irrigation and domestic activities. }\end{array}$ \\
\hline Song Ray Lake & M3 & $\begin{array}{l}\text { The sampling station is located near Ray Lake, which is downstream location. The } \\
\text { water is extensively used for recreational (picnic areas) and agricultural area }\end{array}$ \\
\hline River Ray Bridge & M4 & $\begin{array}{l}\text { Sampling point is near the bridge. The main activity observed in the river is used for } \\
\text { irrigation, industrial, and domestic purpose. }\end{array}$ \\
\hline Suoi Cat & M5 & The sampling location is located near arable land, before a dam \\
\hline Suoi Cao & M6 & The sampling location is located near arable land, after a dam \\
\hline Suoi Vong & M7 & The sampling location is located near agricultural area and pig farm \\
\hline Suoi Doi & M8 & The sampling location is located near industrial, agricultural area, and farm activities \\
\hline Da Den lake & M9 & $\begin{array}{l}\text { The sampling station is located near Da Den lake. The water is extensively used for } \\
\text { domestic, agricultural, industrial, and farm activities }\end{array}$ \\
\hline Dam Loc An & M10 & End of the river, near agricultural, domestic area and livestock \\
\hline
\end{tabular}

\subsection{Developing water quality index (WQI)}

Among 13 physicochemical, the development of WQI for the Ray River was based upon nine water quality parameters such as temperature, $\mathrm{pH}$, turbidity, fecal coliform, dissolved oxygen, biochemical oxygen demand, total phosphates, nitrates and total solids [29]-[31].

We adopted the calculation of WQI were detailed below:

$$
\mathrm{WQI}=\frac{W Q I_{p H}}{100}\left[\frac{1}{5} \sum_{a=1}^{5} W Q I_{a} \times \frac{1}{2} \sum_{b=1}^{2} W Q I_{b} \times W Q I_{c}\right]^{\frac{1}{3}}
$$

Where:

$\mathrm{WQI}_{\mathrm{a}}$ : The calculated WQI value for 5 parameters: $\mathrm{DO}, \mathrm{BOD}_{5}, \mathrm{COD}, \mathrm{N}-\mathrm{NH}_{4}{ }^{+}, \mathrm{P}_{-} \mathrm{PO}_{4}{ }^{3-}$.

WQI $I_{b}$ : The calculated WQI value for 2 parameters: TSS, Tur

WQI $_{\mathrm{c}}$ : The calculated WQI value for the Total Coliform parameter

$\mathrm{WQI}_{\mathrm{pH}}$ : The calculated WQI value for the $\mathrm{pH}$ parameter 
According to the Decision No. 879/QD-TCMT and WQI method, the ratings of water quality was divided into five degrees below (Table 2) [30]-[34].

Table 2. Water quality classification based on WQI value

\begin{tabular}{ccc}
\hline WQI Value & Rating of Water Quality & Color \\
\hline $91-100$ & Excellent & Blue \\
$71-90$ & Good & Green \\
$51-70$ & Medium & Orange \\
$26-50$ & Bad & Yellow \\
$0-25$ & Very bad & Red \\
\hline
\end{tabular}

\section{Results and discussions}

\subsection{Statistics of surface water quality parameters in the DS and RS seasons}

The Ray River is the main source of water for domestic, industrial and agricultural activities; hence, in this study, we evaluate water quality based on two standards of the Ministry of Natural Resources and Environment. In addition, based on the statistics of the surface water, indication of the water quality deterioration was observed in the Ray river basin as parameters did not meet the Vietnamese regulation for surface water QCVN 08:2008 type B1 such as TSS, BOD , COD, $\mathrm{NO}_{2}, \mathrm{NH}_{4}$, coliform. Also, there was pronounced variation in water quality between the dry and rainy seasons (Table 3 ).

Table 3. Statistics of surface water parameters for DS and RS seasons in the Ray river [35]

\begin{tabular}{|c|c|c|c|c|c|c|c|c|c|c|c|c|}
\hline \multirow[b]{2}{*}{ Parameters } & \multirow[b]{2}{*}{ Min } & \multicolumn{4}{|c|}{ Dry season } & \multirow[b]{2}{*}{ Min } & \multicolumn{3}{|c|}{ Rainy season } & \multicolumn{3}{|c|}{$\begin{array}{c}\text { QCVN } \\
08: 2008^{1}\end{array}$} \\
\hline & & Mean & $\operatorname{Max}$ & SD & $\mathrm{CV} \%$ & & Mean & Max & SD & $\mathrm{CV} \%$ & $\mathrm{~A}_{1}$ & $\mathrm{~B}_{1}$ \\
\hline $\mathrm{T}$ & 24.0 & 28.8 & 33.5 & 2.3 & $8.1 \%$ & 22.0 & 27.6 & 31.0 & 3.1 & $11.1 \%$ & - & - \\
\hline$p H$ & 6.8 & 7.3 & 8.1 & 0.4 & $5.1 \%$ & 6.8 & 7.5 & 8.2 & 0.4 & $5.6 \%$ & $6-8.5$ & $5.5-9$ \\
\hline$D O$ & 3.9 & 6.4 & 7.8 & 1.2 & $18.1 \%$ & 4.4 & 6.4 & 7.6 & 1.0 & $15.4 \%$ & $\geq 6$ & $\geq 4$ \\
\hline Tur & 4.0 & 14.5 & 40.9 & 11.8 & $81.0 \%$ & 7.0 & 58.7 & 172.0 & 60.8 & $103.5 \%$ & & \\
\hline$T S S$ & 3.0 & 18.0 & 61.0 & 21.0 & $117.0 \%$ & 3.0 & 66.1 & 214.7 & 77.9 & $118.0 \%$ & 20 & 50 \\
\hline $\mathrm{BOD}_{5}$ & 4.3 & 8.2 & 19.4 & 4.5 & $55.2 \%$ & 4.5 & 7.0 & 12.3 & 2.6 & $36.7 \%$ & 4 & 15 \\
\hline$C O D$ & 3.5 & 15.3 & 41.8 & 10.9 & $71.6 \%$ & 3.3 & 13.3 & 28.2 & 7.2 & $54.5 \%$ & 10 & 30 \\
\hline $\mathrm{Fe}$ & 0.2 & 0.5 & 1.2 & 0.4 & $65.0 \%$ & 0.1 & 1.2 & 2.8 & 1.0 & $84.6 \%$ & 0.5 & 1.5 \\
\hline $\mathrm{N}-\mathrm{NO}_{3}$ & 0.2 & 1.1 & 2.5 & 0.8 & $76.2 \%$ & 0.2 & 0.7 & 2.4 & 0.6 & $94.7 \%$ & 2 & 10 \\
\hline $\mathrm{N}-\mathrm{NO}_{2}$ & 0.0 & 0.0 & 0.1 & 0.0 & $103.2 \%$ & 0.0 & 0.0 & 0.1 & 0.0 & $122.6 \%$ & 0.01 & 0.04 \\
\hline $\mathrm{N}-\mathrm{NH}_{4}$ & 0.3 & 1.2 & 1.9 & 0.5 & $40.6 \%$ & 0.5 & 1.0 & 1.6 & 0.4 & $41.6 \%$ & 0.1 & 0.5 \\
\hline $\mathrm{P}-\mathrm{PO}_{4}$ & 0.0 & 0.1 & 0.2 & 0.0 & $72.5 \%$ & 0.0 & 0.1 & 0.2 & 0.1 & $76.7 \%$ & 0.1 & 0.3 \\
\hline Coliform & 230 & 5107 & 24000 & 7654 & $149.9 \%$ & 2400 & 11240 & 43000 & 12384.2 & $110.2 \%$ & 2500 & 7500 \\
\hline
\end{tabular}

As a result, the average level of $\mathrm{T}$ was $28.8^{\circ} \mathrm{C}$, ranging from 24 to $33.5^{\circ} \mathrm{C}$ and 22 to $31^{\circ} \mathrm{C}$ during DS and RS. Surface water had mean $\mathrm{pH}$ of 7.3 and 7.5 in the DS and RS seasons, respectively. Tur was higher during RS (58.7 NTU) may be due to disturbance and processes of underwater light condition. Moreover, the suspended particles absorb temperature from the sunlight, making turbid waters become warmer, and so reducing the concentration of oxygen in the water. Dissolved Oxygen varied between $3.9-7.8 \mathrm{mg} / \mathrm{L}$ and $4.4-7.6 \mathrm{mg} / \mathrm{L}$ during DS and RS, respectively, which the mean value was both two seasons being $6.4 \mathrm{mg} / \mathrm{L}$. The result DO shows that the water quality was well in the Ray River. The TSS was relatively high in the selected locations, and the mean values were $18 \mathrm{mg} / \mathrm{l}$ and $66.1 \mathrm{mg} / \mathrm{l}$, respectively, which had the SD were 21 and 77.9 during DS and RS, respectively. In addition, TSS in water sample in RS is much higher than that in DS. The increase in TSS may be resulted from the mixing with rain

\footnotetext{
${ }^{1}$ QCVN 08:2008 is the Vietnamese national technical regulation for surface water quality (A1 - for drinking water purposes, B1 - acceptable for irrigation and transportation or other activities that does not require a high quality standard)
} 
water. $\mathrm{NO}_{3}, \mathrm{NO}_{2}, \mathrm{NH}_{4}$, and $\mathrm{PO}_{4}$ were higher during $\mathrm{RS}$ and along highly agricultural, livestock areas may be due to leaching from plant nutrient and fertilizers. The organic pollution was also relatively severe in surface water, with the mean value of $\mathrm{COD}_{\mathrm{Mn}}$ being $15.3 \mathrm{mg} / \mathrm{L}$ and $13.3 \mathrm{mg} / \mathrm{L}$ during DS and RS, respectively. $\mathrm{BOD}_{5}$ varied largely in $\mathrm{DS}$, with the mean and $\mathrm{SD}$ values being $8.2 \mathrm{mg} / \mathrm{L}$ and $19.4 \mathrm{mg} / \mathrm{L}$, respectively. The high $\mathrm{BOD}_{5}$ value can be resulted from farms situated in the upstream of the river as well as effluents from the domestic wastewater and industrial activity. Regarding the Coliform whose standard of surface water is $7500 \mathrm{MPN} / 100 \mathrm{ml}$, it is found that the surface water samples were below the maximum allowance in both two seasons. The mean levels of Coliform were 5107.0 and 11240.0 MPN/100ml during DS and RS.

\subsection{Distribution of water quality parameters in DS and RS seasons respectively}

Box plot was used to represent spatial variation in Ray River water quality, shown in Figure 2. Tur, TSS, Fe, Coliform results indicate an increasing trend of these parameters during RS. This may due to the leaching from farm, livestock, and other anthropogenic activities. Regarding $\mathrm{BOD}_{5}$ and COD, its values were significantly lower in RS (median value of $6.6 \mathrm{mg} / \mathrm{L}$ and 13.25 $\mathrm{mg} / \mathrm{L}$, respectively) than those in DS (which the mean values were $7.0 \mathrm{mg} / \mathrm{L}$ and $13.3 \mathrm{mg} / \mathrm{L}$, respectively). The concentrations of nutrients $\left(\mathrm{NO}_{3}-\mathrm{N}, \mathrm{NO}_{2}-\mathrm{N}, \mathrm{NH}_{4}-\mathrm{N}\right)$ in $\mathrm{RS}$ were all relatively lower than that in DS, see Fig. 2.
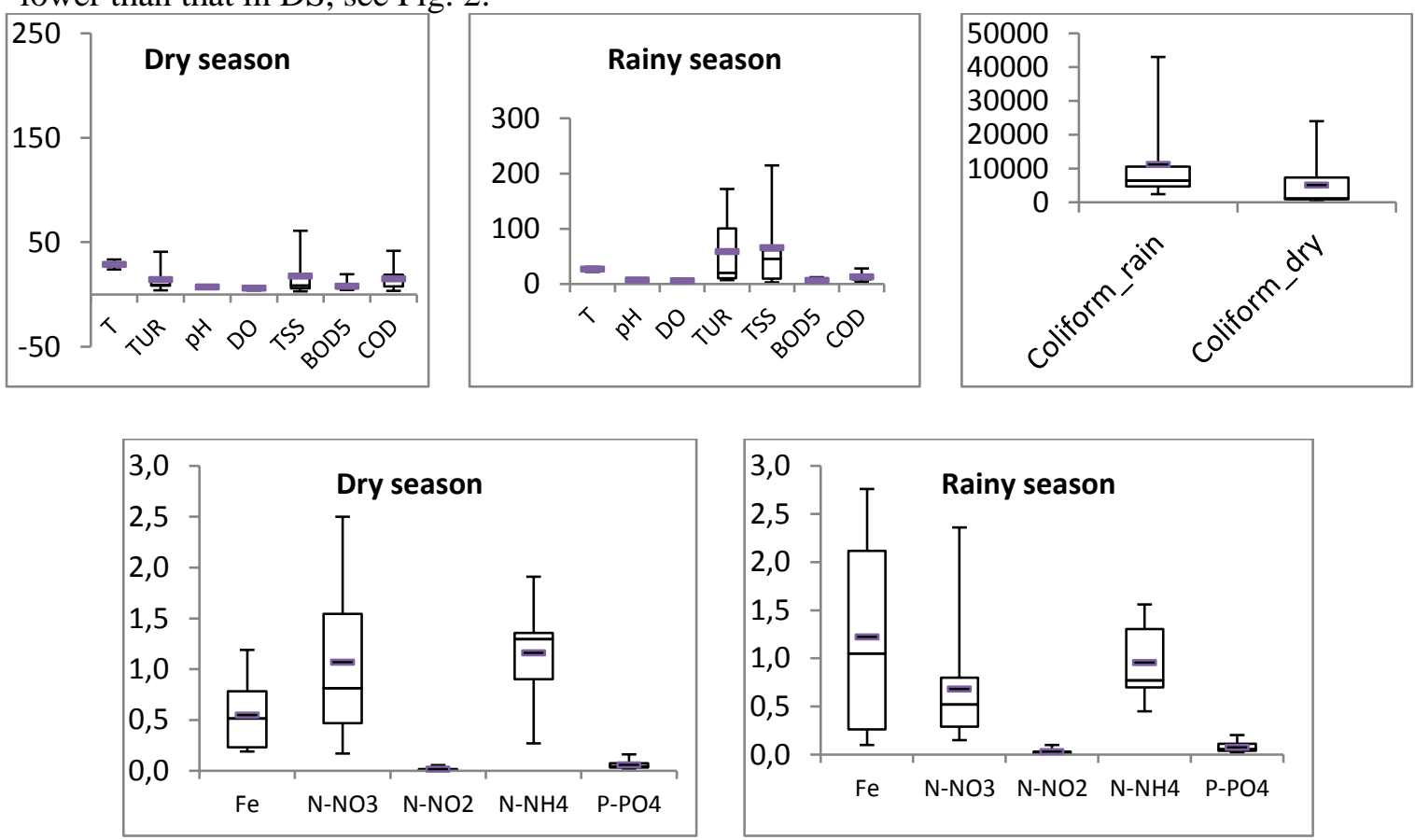

Figure 2. Box plots water quality index calculation in DR and RS seasons respectively

\subsection{Water quality condition based on the WQI}

WQI of Ray river was depicted in Table 4. The analysis of experimental results was made based on the Water Quality Index Decision No. 879/QD-TCMT of various water locations in the study area [34].

Water quality in DS is relatively better than rainy season. The water quality at the locations M4 to M9 in the dry season were ranked good and fall into "A, B" category, except at Hoa Binh waterfall and Dam Loc An where have medium water quality and fall into "C" category. The quality of upstream of the Ray River and River Ray lake were very poor and belongs to "E" category due to the wastewater from farms, industrial zones and agriculture. The water quality of 
the rainy season in the locations M1, M3, M4, M6 and M8 were observed to be of medium quality and classified as "C" category. The sample collected at location M5 was of good quality and was classified as "B" category. Besides, all the sampling areas at M2, M9, M10 of the Ray River were the most polluted since its WQI have the lowest value (Figure 3). This is due to the results of the expansion of industrial, agricultural activities and the increase use of fertilizers, agrochemicals. On the other hand, the high organic load from domestic and livestock wastewater has seriously polluted the Ray River.

Table 4. Results of WQI calculation of the Ray River

\begin{tabular}{|c|c|c|c|c|c|c|c|c|c|c|c|c|}
\hline No & WQIDO & WQIBOD5 & WQICOD & WQINH4 & WQIPO4 & WQITSS & WQITur & WQIColi. & WQI $\mathrm{I}_{\mathrm{pH}}$ & WQI & Description & Class \\
\hline \multicolumn{13}{|c|}{ Dry season } \\
\hline M1 & 100.00 & 74.44 & 100.00 & 23.08 & 100.00 & 100.00 & 93.50 & 35.00 & 100.00 & 64.57 & Medium & $\mathrm{C}$ \\
\hline M2 & 100.00 & 96.25 & 100.00 & 22.78 & 100.00 & 100.00 & 93.33 & 1.00 & 100.00 & 20.08 & Very Bad & $\mathrm{E}$ \\
\hline M3 & 100.00 & 91.25 & 100.00 & 69.17 & 84.50 & 100.00 & 51.25 & 1.00 & 100.00 & 18.88 & Very Bad & $\mathrm{E}$ \\
\hline M4 & 100.00 & 74.17 & 81.50 & 19.54 & 100.00 & 100.00 & 94.17 & 114.00 & 100.00 & 94.00 & Excellent & A \\
\hline M5 & 100.00 & 70.83 & 86.00 & 21.28 & 100.00 & 100.00 & 98.33 & 113.70 & 100.00 & 94.83 & Excellent & A \\
\hline M6 & 69.59 & 72.50 & 100.00 & 23.38 & 100.00 & 100.00 & 94.50 & 122.70 & 100.00 & 95.54 & Excellent & A \\
\hline M7 & 100.00 & 57.25 & 66.50 & 30.50 & 100.00 & 100.00 & 100.0 & 101.00 & 100.00 & 89.44 & Good & B \\
\hline M8 & 49.41 & 77.50 & 73.33 & 28.50 & 100.00 & 100.00 & 85.00 & 120.70 & 100.00 & 90.21 & Excellent & A \\
\hline M9 & 68.74 & 67.78 & 65.00 & 39.50 & 100.00 & 44.50 & 81.67 & 116.50 & 100.00 & 79.44 & Good & B \\
\hline M10 & 100.00 & 39.00 & 35.25 & 23.08 & 100.00 & 48.75 & 43.19 & 115.70 & 100.00 & 68.13 & Medium & $\mathrm{C}$ \\
\hline \multicolumn{13}{|c|}{ Rainy season } \\
\hline M1 & 100.00 & 80.00 & 90.00 & 54.17 & 74.25 & 100.00 & 1.00 & 101.00 & 100.00 & 74.07 & Medium & $\mathrm{C}$ \\
\hline M2 & 68.74 & 86.25 & 100.00 & 22.06 & 100.00 & 100.00 & 95.83 & 1.00 & 100.00 & 19.47 & Very Bad & $\mathrm{E}$ \\
\hline M3 & 91.09 & 77.50 & 80.00 & 23.98 & 91.75 & 49.65 & 1.00 & 89.00 & 100.00 & 54.76 & Medium & $\mathrm{C}$ \\
\hline M4 & 100.00 & 74.44 & 100.00 & 22.90 & 93.75 & 100.00 & 65.50 & 50.00 & 100.00 & 68.66 & Medium & $\mathrm{C}$ \\
\hline M5 & 100.00 & 71.39 & 100.00 & 37.50 & 100.00 & 100.00 & 96.67 & 73.00 & 100.00 & 83.73 & Good & B \\
\hline M6 & 100.00 & 93.75 & 100.00 & 36.00 & 100.00 & 100.00 & 93.33 & 32.00 & 100.00 & 64.30 & Medium & $\mathrm{C}$ \\
\hline M7 & 94.72 & 12.50 & 72.83 & 21.64 & 100.00 & 1.00 & 22.60 & 79.00 & 100.00 & 38.31 & Bad & D \\
\hline M8 & 78.34 & 57.50 & 53.00 & 41.00 & 100.00 & 43.60 & 81.67 & 77.00 & 100.00 & 68.27 & Medium & $\mathrm{C}$ \\
\hline M9 & 72.31 & 78.75 & 91.50 & 37.00 & 100.00 & 1.00 & 1.00 & 1.00 & 100.00 & 4.23 & Very Bad & $\mathrm{E}$ \\
\hline M10 & 50.77 & 72.78 & 64.33 & 45.50 & 100.00 & 47.15 & 80.33 & 1.00 & 100.00 & 16.20 & Very Bad & $\mathrm{E}$ \\
\hline
\end{tabular}

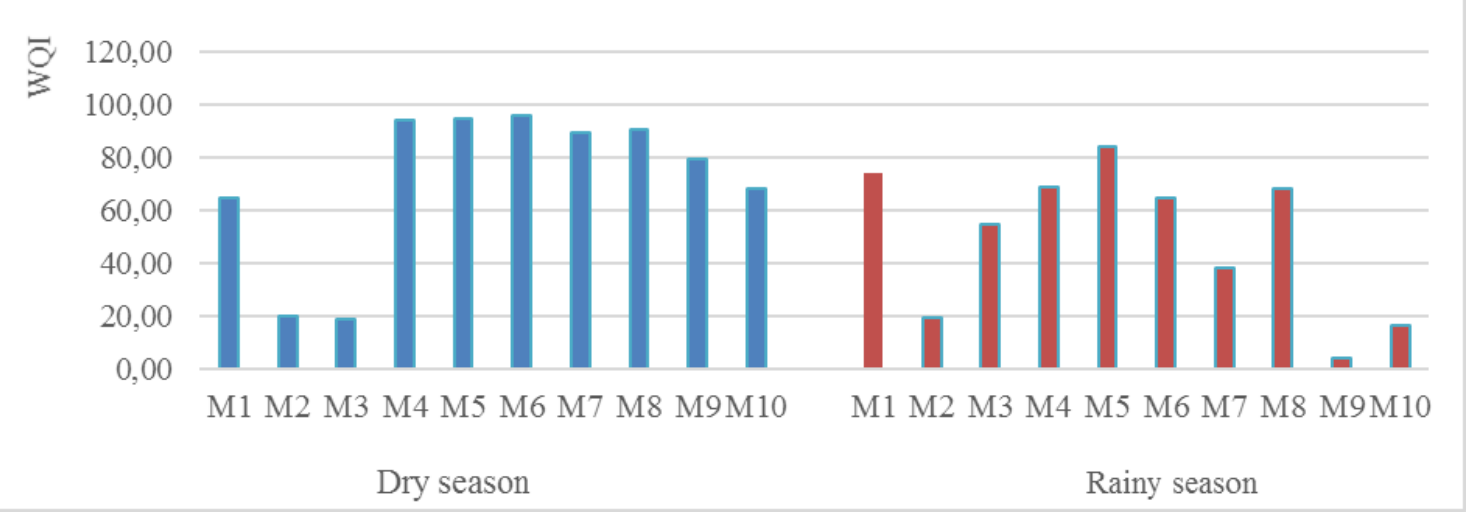

Figure 3. Graph of WQI calculation of Ray River

This study identifies that the single value of WQI has enough and higher sensitivity to evaluate the surface water quality than a long list of values of a large variety of parameters (Figure 3). Using this method could be useful for managers to monitor and assess the quality of surface water in fixed areas [12], [19].

On the other hand, the linear relationship between any two water quality parameters, as measured by the simple correlation coefficient ( $\mathrm{r}$ ), has been presented in Table 5. Correlation analysis will measure the closeness of the relationship between selected variables, if the correlation coefficient is close by +1 or -1 , the linear association between the two variables is 
perfect [36]. DO and temperature are highly interrelated among themselves. Dissolved oxygen concentration in water $(\mathrm{mg} / \mathrm{l})$ is very temperature dependent. Furthermore, the correlation matrix reveals that a relationship exists between $\mathrm{pH}$, coliform and $\mathrm{T}$, as well as between $\mathrm{COD}, \mathrm{BOD}_{5}$ and DO.

Table 5. Correlation coefficient of water quality parameters

\begin{tabular}{|c|c|c|c|c|c|c|c|c|c|c|c|c|c|}
\hline & $T$ & $p H$ & $D O$ & $T U R$ & $T S S$ & $\mathrm{BOD}_{5}$ & $C O D$ & $\mathrm{Fe}$ & $\mathrm{N}-\mathrm{NO}_{3}$ & $\mathrm{~N}-\mathrm{NO}_{2}$ & $\mathrm{~N}-\mathrm{NH}_{4}$ & $\mathrm{P}-\mathrm{PO}_{4}$ & Coli. \\
\hline $\mathrm{T}$ & 1 & & & & & & & & & & & & \\
\hline $\mathrm{pH}$ & 0.728 & 1 & & & & & & & & & & & \\
\hline DO & 0.676 & 0.595 & 1 & & & & & & & & & & \\
\hline TUR & -0.168 & 0.001 & 0.084 & 1 & & & & & & & & & \\
\hline TSS & -0.229 & -0.404 & -0.263 & 0.358 & 1 & & & & & & & & \\
\hline $\mathrm{BOD}_{5}$ & 0.240 & -0.127 & -0.193 & -0.178 & 0.403 & 1 & & & & & & & \\
\hline COD & 0.009 & -0.216 & -0.593 & 0.011 & 0.303 & 0.759 & 1 & & & & & & \\
\hline $\mathrm{Fe}$ & -0.386 & -0.190 & -0.215 & 0.893 & 0.623 & -0.085 & 0.180 & 1 & & & & & \\
\hline $\mathrm{N}-\mathrm{NO}_{3}$ & -0.133 & -0.327 & 0.253 & 0.113 & 0.561 & 0.374 & -0.123 & 0.165 & 1 & & & & \\
\hline $\mathrm{N}-\mathrm{NO}_{2}$ & -0.187 & 0.058 & -0.017 & 0.815 & 0.339 & -0.312 & -0.061 & 0.816 & -0.124 & 1 & & & \\
\hline $\mathrm{N}-\mathrm{NH}_{4}$ & -0.075 & 0.005 & 0.260 & -0.145 & 0.147 & 0.084 & -0.386 & -0.178 & 0.690 & -0.451 & 1 & & \\
\hline $\mathrm{P}_{-} \mathrm{PO}_{4}$ & -0.059 & 0.155 & 0.283 & 0.687 & -0.185 & -0.215 & -0.068 & 0.486 & 0.110 & 0.448 & -0.058 & 1 & \\
\hline Coli. & -0.752 & -0.583 & -0.745 & -0.397 & -0.107 & -0.201 & 0.128 & -0.111 & -0.222 & -0.239 & -0.127 & -0.261 & 1 \\
\hline
\end{tabular}

\section{Conclusion}

This study aims to assess the water quality in two seasons (dry and rainy season) at the Ray River and to determine thirteen parameters the main parameters influence water quality, which are considered for the prediction of the WQI at the ten locations. For the implementation of the single locations, thirteen different parameters were used and the predictive results were evaluated using determination WQI, mean, and correlation coefficient. The results showed that the quality of surface water was strongly influenced by anthropogenic activities including industrial effluents, phosphate fertilizers in agriculture, and livestock activities. The water quality at the M2, M3 (dry season) and M2, M9, M10 (rainy season) locations are found to be the most polluted. WQI in dry season was significantly higher than that in the rainy season. In generally, water quality condition was evaluated as "medium and poor" in terms of WQI, while the state varied obviously during the two seasons, with "good" ranking in dry season. Water quality in the study area is gradually reaching the alarming stage so that proper planning is essential to this venture to preserve the source water quality.

\section{REFERENCES}

[1] J. Wang, L. Da, K. Song, and B.-L. Li, "Temporal variations of surface water quality in urban, suburban and rural areas during rapid urbanization in Shanghai, China," Environmental Pollution, vol. 152, no. 2, pp. 387-393, 2008.

[2] A. S. Todd, A. H. Manning, P. L. Verplanck, C. Crouch, D. M. McKnight, and R. Dunham, "Climatechange-driven deterioration of water quality in a mineralized watershed," Environmental Science Technology, vol. 46, no. 17, pp. 9324-9332, 2012.

[3] S. R. Carpenter, N. F. Caraco, D. L. Correll, R. W. Howarth, A. N. Sharpley, and V. H. Smith, "Nonpoint pollution of surface waters with phosphorus and nitrogen," Ecological Applications, vol. 8, no. 3, pp. 559-568, 1998.

[4] M. Milovanovic, "Water quality assessment and determination of pollution sources along the Axios/Vardar River, Southeastern Europe," Desalination, vol. 213, no. 1-3, pp. 159-173, 2007.

[5] P. Samantray, B. K. Mishra, C. R. Panda, and S. P. Rout, "Assessment of water quality index in Mahanadi and Atharabanki Rivers and Taldanda Canal in Paradip area, India," Journal of Human Ecology, vol. 26, no. 3, pp. 153-161, 2009.

[6] V. Simeonov, J. Stratis, C. Samara, G. Zachariadis, D. Voutsa, A. Anthemidis, and T. Kouimtzis, "Assessment of the surface water quality in Northern Greece," Water Research, vol. 37, no. 17, pp. 4119-4124, 2003. 
[7] P. Simeonova, V. Simeonov, and G. Andreev, "Water quality study of the Struma river basin, Bulgaria (1989-1998)," Central European Journal of Chemistry, vol. 1, no. 2, pp. 121-136, 2003.

[8] S. Panda, V. Garg, and I. Chaubey, "Artificial neural networks application in lake water quality estimation using satellite imagery," Journal of Environmental Informatics, vol. 4, no. 2, pp. 65-74, 2004.

[9] K. P. Singh, A. Basant, A. Malik, and G. Jain, "Artificial neural network modeling of the river water quality - a case study," Ecological Modelling, vol. 220, no. 6, pp. 888-895, 2009.

[10] N. H. Than and T. LY CD, "Application of a Neural Network Technique for Prediction of the Water Quality Index in the Dong Nai River, Vietnam," Journal of Environmental Science Engineering B, vol. 5, pp. 363-370, 2016.

[11] A. Akkoyunlu and M. E. Akiner, "Pollution evaluation in streams using water quality indices: A case study from Turkey's Sapanca Lake Basin," Ecological Indicators, vol. 18, pp. 501-511, 2012.

[12] X. Nong, D. Shao, H. Zhong, and J. Liang, "Evaluation of water quality in the South-to-North Water Diversion Project of China using the water quality index (WQI) method," Water Research, vol. 178, 2020, Art. no. 115781.

[13] A. D. Sutadian, N. Muttil, A. G. Yilmaz, and B. Perera, "Development of river water quality indicesa review," Environmental Monitoring Assessment, vol. 188, no. 1, 2016, Art. no. 58.

[14] D. Katyal, "Water quality indices used for surface water vulnerability assessment," International Journal of Environmental Sciences, vol. 2, no. 1, pp. 154-173, 2011.

[15] I. Akoteyon, A. Omotayo, O. Soladoye, and H. Olaoye, "Determination of water quality index and suitability of urban river for municipal water supply in Lagos-Nigeria," European Journal of Scientific Research, vol. 54, no. 2, pp. 263-271, 2011.

[16] W. Sun, C. Xia, M. Xu, J. Guo, and G. Sun, "Application of modified water quality indices as indicators to assess the spatial and temporal trends of water quality in the Dongjiang River," Ecological Indicators, vol. 66, pp. 306-312, 2016.

[17] M. Nasirian, "A new water quality index for environmental contamination contributed by mineral processing: a case study of Amang (Tin Tailing) processing activity," Journal of Applied Science, vol. 7, no. 20, pp. 2977-2987, 2007.

[18] Ş. Şener, E. Şener, and A. Davraz, "Evaluation of water quality using water quality index (WQI) method and GIS in Aksu River (SW-Turkey)," Science of the Total Environment, vol. 584, pp. 131$144,2017$.

[19] Z. Wu, X. Lai, and K. Li, "Water quality assessment of rivers in Lake Chaohu Basin (China) using water quality index," Ecological Indicators, vol. 121, 2021, Art. no. 107021.

[20] H. H. Nguyen, G. Everaert, W. Gabriels, T. H. Hoang, and P. L. Goethals, "A multimetric macroinvertebrate index for assessing the water quality of the Cau river basin in Vietnam," Limnologica, vol. 45, pp. 16-23, 2014.

[21] O. D. Vietnam, "River and Lake," 2018. [Online]. Available: https://vietnam.opendevelopmentmekong.net/vi/topics/rivers-and-lakes/\#: :text=Vi\%E1\%BB\%87t\% 20Nam\%20c\%C3\%B3\%20h\%E1\%BB\%87\%20th\%E1\%BB\%91ng,\%C4\%91\%C3\%B3\%20c\%C3\%B $3 \% 20109 \% 20$ s\%C3\%B4ng\%20ch\%C3\%ADnh. [Accessed Dec. 20, 2020].

[22] T. T. Nguyen ., Némery, J., Gratiot, N., Strady, E., Tran, V. Q., Nguyen, A. T., . . . Peyne, A. "Nutrient dynamics and eutrophication assessment in the tropical river system of Saigon-Dongnai (southern Vietnam)," Science of the Total Environment, vol. 653, pp. 370-383, 2019.

[23] L. V. T. Noi and V. Nitivattananon, "Assessment of vulnerabilities to climate change for urban water and wastewater infrastructure management: Case study in Dong Nai river basin, Vietnam," Environmental Development, vol. 16, pp. 119-137, 2015.

[24] P. Thi Minh Hanh, S. Sthiannopkao, D. T. Ba, and K.-W. Kim, "Development of water quality indexes to identify pollutants in Vietnam's surface water," Journal of Environmental Engineering, vol. 137, no. 4, pp. 273-283, 2011.

[25] T. T. Lan and N. P. Long, "Assessment of surface water quality by water quality index (WQI) at the Cai Sao canal, An Giang province, Vietnam," Livestock Research for Rural Development, vol. 23, no. 7, pp.151-157, 2011.

[26] H. Pham, M. Rahman, N. Nguyen, P. L. Vo, T. L. Van, and H. Ngo, "Assessment of Surface Water Quality Using the Water Quality Index and Multivariate Statistical Techniques A Case Study: The 
Upper Part of Dong Nai River Basin, Vietnam," Journal of Water Sustainability, vol. 7, pp. 225-245, 2017.

[27] Statistical and Office, "Statistical Yearbook of Ba Ria - Vung Tau 2018," 2018. [Online]. Available: http://www.cosis.vn/khct-brvt/. [Accessed Dec. 15, 2020].

[28] W. E. Federation and A. Association, Standard methods for the examination of water and wastewater. American Public Health Association: Washington, DC, USA, 2005.

[29] R. M. Brown, N. I. McClelland, R. A. Deininger, and R. G. Tozer, A Water Quality Index- Do We Dare. Water Sewage Works, 1970.

[30] D. Kumar and B. J. Alappat, "NSF-water quality index: does it represent the experts' opinion?," Practice Periodical of Hazardous, toxic, radioactive waste Management, vol. 13, no. 1, pp. 75-79, 2009.

[31] V. E. Administration, "WQI water quality index calculation method," 2010. [Online]. Available: https://thuvienphapluat.vn/van-ban/Tai-nguyen-Moi-truong/Quyet-dinh-711-QD-TCMT-2015-Botrong-so-trong-cong-thuc-tinh-toan-chi-so-chat-luong-nuoc-286911.aspx. [Accessed Dec. 15, 2020].

[32] S. Jonnalagadda and G. Mhere, "Water quality of the Odzi River in the eastern highlands of Zimbabwe," Water Research, vol. 35, no. 10, pp. 2371-2376, 2001.

[33] S. Tyagi, B. Sharma, P. Singh, and R. Dobhal, "Water quality assessment in terms of water quality index," American Journal of Water Resources, vol. 1, no. 3, pp. 34-38, 2013.

[34] M. O. N. R. A. Environment, "Decision 879 / QD-TCMT guiding calculation of water quality index," 2011. [Online]. Available: https://m.thuvienphapluat.vn/van-ban/tai-nguyen-moi-truong/Quyet-dinh879-QD-TCMT-so-tay-huong-dan-ky-thuat-tinh-toan-chi-so-126098.aspx. [Accessed Dec. 15, 2020].

[35] M. O. N. R. A. Environment, QCVN 08:2008 is the Vietnamese national technical regulation for surface water quality, 2008.

[36] M. al-Hadithi, "Application of water quality index to assess suitability of groundwater quality for drinking purposes in Ratmao-Pathri Rao watershed, Haridwar District, India," Am J Sci Ind Res, vol. 3, no. 6, pp. 395-402, 2012. 